\title{
"COSO" Internal Control Analysis on Account Receivable (Case Study in Astra Sedaya Finance Branch Cirebon)
}

\author{
Shella Oktavia Hermanto Putri ${ }^{1}$, Dewi Kusumowati ${ }^{2 *}$ \\ ${ }^{1}$ Program S1 Akuntansi, Fakultas Ekonomi dan Bisnis, \\ Universitas Merdeka Malang, Indonesia \\ ${ }^{2}$ Fakultas Ekonomi dan Bisnis, Universitas Merdeka Malang, Indonesia \\ *dewi.kusumowati@unmer.ac.id
}

\begin{abstract}
The purpose of this study is to determine the internal control system of accounts receivable, and to determine whether internal control analysis of model "COSO" on Account Receivable has been implemented at PT. Astra Sedaya Finance branch Cirebon. Primary \& secondary data are analyzed based on the components of internal control established by the Committee of Sponsoring Organizations (COSO). The components of internal control that will be analyzed in this study, and then have 5 (five) element: 1) Control Environmental, 2) Risk Assessment, 3) Control Activities, 4) Information and Communication, and 5) Monitoring Activities. Research result Internal Control of accounts receivable at the Astra Sedaya Finance Cirebon Branch had been found effective, where the company's management had adopted the basic concepts and principles of internal control by standard operating procedures that had been set by the company. The overall system of internal control over accounts receivable at the Astra Sedaya Finance was effective enough, where management had implemented the principles of internal control in accordance with COSO, but there has been a weakness that the company still had not been put on the application system for recording and completion of documents receivable for companies in which still using manual computerized.
\end{abstract}

Keywords: Account Receivable, Internal Control System of Model "COSO”

\section{INTRODUCTION}

In the development of the system of selling goods or services at this time, the company can use the payment in cash or on credit. Accounts receivable credit company is one of the most important current assets in the total assets of the company. Receivables can bear the risk for the company to carry out a credit payment system if the consumer does not perform its payment obligations. But until now when consumers make payments on credit, for its calculation will be far greater than the payment in cash. Thus the credit sales will arise accounts receivable.

Accounts receivable can arise not only due to the sale of merchandise on credit, but it can be also due to other things, such as receivables to employees, accounts receivable for the sale of fixed assets on credit, accounts receivable due to the sale of shares in a credit or down payment for the purchase or contract of employment more. According to Syakur (2015), receivable is a claim to the company Another on the consequence of events in the past in the form 
of money, goods, services or in the form of non-earning assets other cash that should be collected on the due date. One way to find out is to implement internal control.

Internal control is a system that can overcome fraud and address of doubtful debts. With the internal controls, companies can learn how to overcome it. So, the company can maintain its assets, and provide better information. This internal control aims to determine the effectiveness and efficiency of the company. A company engaged in part financing (finance), one of which is focused on the credit payment system.

Control of control according to the COSO internal control (Committee of Sponsoring Organizations) that the organization and the internal control is an integral part of the basic management activities. Internal control can only provide reasonable assurance, not absolute desire. This confirms that no matter how well the internal controls designed and operated, can provide only reasonable assurance, cannot be fully effective in achieving the objectives of internal control although it has been designed and structured with the best. Even how good internal control is ideal in design, but its success depends on the competition and the constraints of the implementation and not in spite of various limitations.

Astra Sedaya Finance, a subsidiary of PT Astra International, where Astra Sedaya Finance is a company engaged in the financing of financial services the car, especially in the area of financing on credit to potential borrowers who want to buy a vehicle either in financing a new car (new car), financing a used car (used car), or heavy equipment. Motor vehicles are one of the many products on credit by consumers. At this time many emerging various types of new vehicles and discount sophistication in various vehicles. Astra Sedaya Finance so always keeps and maintain for consumers trying to stay ahead of the competitors who offer credit financing. Control more than $50 \%$ share of the automotive market in Indonesia (ACCelerate, 2011).

\section{Accounts Receivable}

Accounts Receivable (Accounts Receivables) one element of the company's current assets in the balance sheet arising from the sale of goods, services or credit to borrowers, in general, given the payment due in 30 days up to 90 days. If interpreted in a broad sense, a receivable is a guide to the other party, in the form of fees or goods sold on credit. How this credit sale is a way that is usually done in the business world in order to attract customers purchasers of goods and services within the company. These receivables arise, due to the sale of goods or services from a company. Where in the payments made by the parties concerned, will be made after the date of the purchase transaction.

According to Fahmi (2016) states that a receivable is a form of sales made by a company in which payment is not made in cash, but is progressive. Definition of receivables by Hery (2013) describes the accounts receivable is as a storm.

\section{Internal Control}

According to Tuanakotta (2015), an internal control framework, processes, and policies that are arranged by management closely in ensuring the financial reporting are reliable and appropriate financial reporting framework applicable accounting. Meanwhile, according to Mulyadi (2016), namely the structure of the internal control system, method and size of the company in maintaining the company's assets, accounting data reliability and checking the accuracy and efficiency as well as making compliance with company policy.

Based on the above definition can be concluded that internal control is policy and procedures that are executed by a company, the management and employees in a company to provide adequate assurance about the achievement of the objectives of the entity's financial reporting constraints, effective, and its efficiency of operation. 
Internal Control Model "COSO"

Internal controls by the Committee of Sponsoring Organizations of the Treadway Commission (COSO) of the Executive Summary (2013) defines as follows: "Internal control is a process, effected by an entity's board of directors, management, and other personnel, designed to provide reasonable assurance regarding the achievement of objectives Relating to operations, reporting, and compliance". According to COSO (2013) elements of internal control are as follows: Internal control consists of five integrated components, consists of: 1) Control environment, 2) Risk assessment, 3) Control activities, 4) Information and communication, and 5) Monitoring activities

\section{METHOD}

In accordance with the problems with the problems in this study, the variables studied are: 1) Account Receivable, account receivable is the right amounts of cash to the other party as a results of economic transactions, consists of: (a) new car financing, (b) used car financing, (c) customer to customer (C2C) financing, (d) retail commercial financing, (e) fleet commercial financing; 2) Internal Control Model "COSO", consists of: (a) control environment, can be defined as standard equipment, processes, and structures that provide the basis implement internal control throughout the organization; (b) risk assessment, involving a dynamic and interactive process to identify and assess risks to the achievement of the whole purpose of these entities are considered relative to defined risk tolerance; (c) control activities, actions defined by the policies and procedures that help ensure that management directive to reduce risks to the achievement of the goals; (d) information and communication, that is very important information for each entity to carry out the responsibilities of internal control to support the achievement of this objectives; (e) monitoring activities, evaluation activities with some from of what a sustainable nature, separately or as a combination of both is used to determine whether each of the five component of internal control affects the functions in each component, present and functional.

Data sources are primary and secondary data. Primary data in this study are obtained directly by interview the employee through the branch manager, A/R Management, and employee that are directly related objects in meticulous then on though researchers are: 1) The main obstacle cause of bad debts from customer who are in arrears, 2) Procedure credit, 3) Recruitment employee, and 4) The employee performance appraisal. Secondary data in this study are: 1) Organizational structure, 2) Account receivable data, and 3) Sales data

All data analyzed by descriptive method. Meanwhile, the stages are first, collecting data that is trying to describe and secondly, interpret the object in accordance with what it is. The technique used to analyze the data in this study is qualitative analysis methods. Data were analyzed based on the components of internal control established by the Committee of Sponsoring Organizations (COSO). The following is a list of the components of internal control that will be analyzed in this study : 1) Control Environmental, describes the organizational structure, integrity, and competence as well as meeting activity; 2) Risk Assessment, the control of the company against account receivable to reduce the risk of bad debts; 3) Activities Control: (a) Activities of interview, (b) Implementation of Standard Operating Procedure (SOP), (c) Activities segregation of duties performed by each employee, (d) Activities related documents authorization procedures, (e) Activities related to employee performance appraisal; 4) Information and Communication, consists of: (a) The documentation required for the procedures for granting and collection of account receivable to customers, (b) Information resulting from the procedure, (c) Management policies in conveying information; and 5) Monitoring 
Activities, monitoring activities related to the development of account receivable.

\section{RESULT AND DISCUSSION Account Receivable}

Arrears (overdue) payment of accounts receivable at Astra Credit Companies Branch Cirebon divided in some range time, namely ARHO (Accounts Receivable Handling Officer) 0-7 days and 8-30 days, ARRO (Accounts Receivable Remedial Officer) 31-60 days, REMO 1 (Remedial Officer) 61-90 days, REMO 2 (Remedial Officer) 91-120 days, REMO 3 (Remedial Officer) 121-150 days, NCI > 150 days. For a sense of the previous sentence, that the above 7 days overdue, overdue above 30 days overdue over 60 days, over 120 days overdue, and overdue above 160 days (write off). Arrears or overdue is clearly going to cause harm to the company and affect the survival of the company.

Table 1. Account Receivable Aging Schedule December 31, 2018 (in billion IDR)

\begin{tabular}{lccc}
\hline $\begin{array}{c}\text { Age } \\
\text { (days) }\end{array}$ & $\begin{array}{c}\text { Amount } \\
\text { (IDR) }\end{array}$ & $\begin{array}{c}\text { Percentage } \\
\text { Estimated } \\
\text { to be } \\
\text { Uncollectible }\end{array}$ & $\begin{array}{c}\text { Required } \\
\text { Balance in } \\
\text { Allowance } \\
\text { (IDR) }\end{array}$ \\
\hline $0-7$ & 1.188 .707 & $1 \%$ & 11.887 \\
$8-30$ & 54.627 & $8 \%$ & 4.370 \\
$31-60$ & 18.080 & $18 \%$ & 3.254 \\
$61-90$ & 7.943 & $23 \%$ & 1.827 \\
$91-120$ & 3.621 & $26 \%$ & 941 \\
$121-150$ & 4.823 & $30 \%$ & 1.447 \\
Year end balance of allowance for & \\
doubtful accounts & & 23.727 \\
\hline
\end{tabular}

Source: Astra Sedayu, 2018

As shown at table 1, Astra Sedaya Finance Branch Cirebon in 2015-2018 for 4 (four) years, then the results can be obtained for the level of accounts turnover Astra Sedaya Finance as follows:

Table 2. Receivable Turnonver Rate 2015-2018

\begin{tabular}{cccc}
\hline Year & Sale (IDR) & $\begin{array}{c}\text { Receivables } \\
\text { Average (IDR) }\end{array}$ & $\begin{array}{c}\text { Receivable } \\
\text { Turnover } \\
\text { Rate }\end{array}$ \\
\hline 2015 & 500.211 .002 .929 .586 & 1.029 .401 .254 .132 & $4 \mathrm{x}$ \\
2016 & 520.374 .629 .070 .270 & 1.055 .721 .366 .254 & $5 \mathrm{x}$ \\
2017 & 502.286 .020 .419 .573 & 1.344 .019 .730 .081 & $4 \mathrm{x}$ \\
2018 & 527.229 .105 .641 .384 & 1.560 .425 .073 .074 & $3 \mathrm{x}$ \\
\hline
\end{tabular}

Source: Astra Sedayu, 2018
The main obstacle is the cause of bad debts from customers who are in arrears: 1) Customer is difficult to contact by telephone, 2) Customer often slow installment payments, 3) Customer can not be found in place (home, boarding house, and shop), and 4) Customer objected to paying installments until paid off.

\section{Accounts Receivable Analysis According to the Internal Control Model "COSO" At Astra Sedaya Finance Branch Cirebon \\ 1. Control Environment}

a. Organizational Structure, a company gives an overview of the position and the relationship between all units in the company to enable the achievement of communication, coordination, and integration of all activities of the organization both vertically and horizontally.

b. Integrity, uphold integrity and ethical values. Between the one with other parts of the company is integral and interconnected. The company have work experience, companies pay attention to the educational back grounds.

c. Competence, the employee has competence of good human resource improving the company's performance

d. Meeting Activities, routines meeting activities carried out every morning from Monday to Friday and briefing the entire department on Saturday, meeting carried out by a separate section and with other parts

2. Risk Assessment

Management companies are always trying to minimize credit risk, which will affect the accounts receivable. Perform routine management and billing notice in installments. Management continues to strive to minimize the risk of bad debts by directing the customer to pay the way through the application. Management is implementing the standard operating procedure (SOP) strict in the implementation of direct billing installments paid to the developer. 
3. Control Activities

a. Activities carried out by the approval of credit analysis

b. The application of Standard Operating Procedure (SOP)

c. Activities segregation of duties by each part or function related to accounts receivable

d. Documentation Activity against account receivable

e. Reconciliation

f. Activities on the employee performance appraisal related to the accounts receivable department

4. Information and Communications

a. Information from the surveyor on the condition of borrowers and debtors at this time

b. Information from the sales officer regarding conditions of sales showroom/dealer today

c. Data on the payment history of borrowers to finance else

\section{Monitoring Activities}

Has outlined the responsibilities of the respective personnel clearly. The smoothness of account receivable is the responsibility for each person in charge of account receivable. Because it is part of the other parts are interrelated. Management always monitored by the information of aging schedule report.

Table 3. Summary of COSO Analysis

\begin{tabular}{|c|c|c|c|}
\hline No & $\begin{array}{c}\text { Aspects of } \\
\text { Internal Control } \\
\text { Procedures }\end{array}$ & $\begin{array}{c}\text { level } \\
\text { Control }\end{array}$ & Reason \\
\hline 1 & $\begin{array}{l}\text { Environmental } \\
\text { control of } \\
\text { accounts } \\
\text { receivable }\end{array}$ & Strong & $\begin{array}{l}\text { Have an organizational } \\
\text { structure and segregation } \\
\text { of duties. Management } \\
\text { companies pay enough } \\
\text { attention to both the } \\
\text { internal control of } \\
\text { accounts receivable, both } \\
\text { in terms management to } \\
\text { monitoring trade } \\
\text { receivables }\end{array}$ \\
\hline 2 & $\begin{array}{l}\text { Risk Assessment } \\
\text { for trade } \\
\text { receivables }\end{array}$ & Strong & $\begin{array}{l}\text { Management companies } \\
\text { are always trying to } \\
\text { minimize credit risk, } \\
\text { which will affect the } \\
\text { accounts receivable. } \\
\text { Perform routine } \\
\text { management and billing } \\
\text { notice in installments. }\end{array}$ \\
\hline
\end{tabular}

\begin{tabular}{|c|c|c|c|}
\hline No & $\begin{array}{c}\text { Aspects of } \\
\text { Internal Control } \\
\text { Procedures }\end{array}$ & $\begin{array}{c}\text { level } \\
\text { Control }\end{array}$ & Reason \\
\hline 3 & $\begin{array}{l}\text { Activities } \\
\text { approval of the } \\
\text { contract/ MOU } \\
\text { with customers }\end{array}$ & Strong & $\begin{array}{l}\text { The Company has } \\
\text { established a credit } \\
\text { committee an authorized } \\
\text { to determine whether or } \\
\text { not the prospective } \\
\text { customer is given credit. }\end{array}$ \\
\hline 4 & $\begin{array}{l}\text { Standard } \\
\text { Operating } \\
\text { Procedure (SOP) } \\
\text { Company }\end{array}$ & Strong & $\begin{array}{l}\text { The company has a } \\
\text { Standard Operating } \\
\text { Procedure (SOP) related } \\
\text { receivable is written so } \\
\text { know the limits of its } \\
\text { authority }\end{array}$ \\
\hline 5 & $\begin{array}{l}\text { Activities } \\
\text { organizational } \\
\text { structure and } \\
\text { segregation of } \\
\text { duties }\end{array}$ & Strong & $\begin{array}{l}\text { For showing the } \\
\text { separation of duties and } \\
\text { responsibilities and the } \\
\text { delegation of authority. } \\
\text { The organizational } \\
\text { structure of the company } \\
\text { arranged a straight line } \\
\text { that states the } 3 \\
\text { commands and } \\
\text { leadership }\end{array}$ \\
\hline 6 & $\begin{array}{l}\text { Activities } \\
\text { documentation } \\
\text { and authorization } \\
\text { documents }\end{array}$ & Strong & $\begin{array}{l}\text { The Company has } \\
\text { implemented the } \\
\text { documentation activity } \\
\text { and related documents } \\
\text { authorizing the receipt of } \\
\text { cash or installment until } \\
\text { with the recording based } \\
\text { on the functions and } \\
\text { parts. }\end{array}$ \\
\hline 7 & $\begin{array}{l}\text { Performance } \\
\text { assessment } \\
\text { activities in } \\
\text { meeting the } \\
\text { targets in the } \\
\text { disbursement of } \\
\text { trade receivables }\end{array}$ & Strong & $\begin{array}{l}\text { Employees will be } \\
\text { assessed when they } \\
\text { fulfill the target of every } \\
\text { month and will be given } \\
\text { incentives in the } \\
\text { payment of salaries. }\end{array}$ \\
\hline 8 & $\begin{array}{l}\text { The adequacy of } \\
\text { information } \\
\text { resulting from the } \\
\text { procedure of } \\
\text { granting and } \\
\text { collection of } \\
\text { accounts } \\
\text { receivable }\end{array}$ & Strong & $\begin{array}{l}A R H O \text { always remind } \\
\text { the customer for } \\
\text { payment before maturity. } \\
\text { Reminded by telephone } \\
\text { or SMS (Short Message } \\
\text { Service) }\end{array}$ \\
\hline 9 & $\begin{array}{l}\text { In conveying } \\
\text { information } \\
\text { management } \\
\text { policy }\end{array}$ & Strong & $\begin{array}{l}\text { Because AR / } \\
\text { Management always do } \\
\text { a briefing or a meeting } \\
\text { every morning, and } \\
\text { every employee ARHO } \\
\text { present the results of the } \\
\text { collection of accounts } \\
\text { receivable from } \\
\text { customers. }\end{array}$ \\
\hline 10 & $\begin{array}{l}\text { Monitoring } \\
\text { activities related } \\
\text { to the } \\
\text { development of } \\
\text { trade receivables }\end{array}$ & Strong & $\begin{array}{l}\text { Because Collection head } \\
\text { always reminded to } \\
\text { ARHO and sales officer } \\
\text { and surveyor for any } \\
\text { important information } \\
\text { that should do them. } \\
\text { Besides, the collection } \\
\text { head also took in charge } \\
\text { directly in handling a } \\
\text { customer who has been } \\
\text { overdue for more than } \\
\text { three months }\end{array}$ \\
\hline 11. & $\begin{array}{l}\text { Adequacy of } \\
\text { documents } \\
\text { resulting from the } \\
\text { procedure of } \\
\text { granting and }\end{array}$ & Weak & $\begin{array}{l}\text { There was an ACC YES } \\
\text { application to facilitate } \\
\text { online transactions based } \\
\text { on installment } \\
\text { payments. The company }\end{array}$ \\
\hline
\end{tabular}




\begin{tabular}{|c|c|c|c|}
\hline No & $\begin{array}{c}\text { Aspects of } \\
\text { Internal Control } \\
\text { Procedures }\end{array}$ & $\begin{array}{c}\text { level } \\
\text { Control }\end{array}$ & Reason \\
\hline & $\begin{array}{l}\text { collection of } \\
\text { accounts } \\
\text { receivable }\end{array}$ & & $\begin{array}{l}\text { already uses a system of } \\
\text { recording accounts in } \\
\text { which receivable } \\
\text { document is } \\
\text { computerized. However, } \\
\text { application systems have } \\
\text { not been made yet } \\
\text { therefore the completion } \\
\text { of the document is still } \\
\text { conducted manually. }\end{array}$ \\
\hline
\end{tabular}

Based on the summary of data at table 3, the research findings are: 1) Internal Control of accounts receivable at the Astra Sedaya Finance Cirebon Branch had been effective, where the company's management had adopted the basic concepts and principles of internal control by standard operating procedures that had been set by the company, and 2) The overall system of internal control over accounts receivable at the Astra Sedaya Finance was effective enough, where management had implemented the principles of internal control in accordance with COSO.

\section{Conclusion}

As a conclusion, the whole study had a strong degree of control. So, it can be stated that the system of internal control over trade receivables as a whole has been effective. If internal controls applied by a good company and meet the standards, then it is certain goals and objectives are achieved in maximum way. So with such an effective control system can be used by management to plan and control the operation of the company, to help providing reliable accounting information for financial reporting, and ensure compliance with applicable laws and regulations. So that fraud risk management can be minimalized.

\section{REFERENCES}

ACCelerate. (2011). ACCelerate (8 Ed.). Desantirahayu. (2017). Analisis Pengendalian Intern Model "COSO" terhadap Piutang Usaha. Akademika, 15(1).
Fahmi, I. (2016). Manajemen Sumber Daya Manusia. Yogyakarta: Alfabeta.

Hery. (2013). Auditing Pemeriksaan Akuntansi 1 Cetakan Pertama. Jakarta: Caps (Center of Academic Publishing Service).

Iia, A. (2013). Organisasi Profesi Pendiri Kajian Coso (Committee of Sponsoring Organization). Amerika Serikat.

Ikatan Akuntansi Indonesia (IAI). (2015). Standar Akuntansi Keuangan. Psak No. 9: Penyajian Aktiva Lancar dan Kewajiban Jangka Pendek. Jakarta: Salemba Empat.

Janvrin, D., And E. Payne. (2012). The Updated COSO Internal Control Integrated Framework: Recomendations and Opportunities For Future Reasearch. Journal of Information Systems, 26 (2)

Klamm, B. K., And M. W. Watson. (2009).

Sox 404 Reported Internal Control Weaknesses: A Test of COSO Framework Components and Information Technology. Journal of Information Systems (23) 2, 1-23.

Mulyadi. (2014). Auditing (6 Ed.). Jakarta: Salemba Empat.

Mulyadi. (2016). Sistem Akuntansi (4 Ed.). Jakarta: Salemba Empat.

Pontoh, W. (2013). Akuntansi Konsep dan Aplikasi. Jakarta: Penerbit.

Runtu, E. (2016). Analisis Pengendalian Intern Piutang Usaha Pada PT Bussan Auto Finance (Baf) Manado. Jurnal Emba, (4).1, 536-545.

Santoso, P. (2012). Evaluasi Penerapan Internal Control Berdasarkan Kerangka Coso Pada Divisi Kartu Kredit Di Bank "X". Jurnal Ilmiah, Universitas Surabaya, 1 (1)

Schneider, K., And L. Becker. (2011). Using The Coso Model of Internal Control as A Framework for Ethics Initiatives In Business School. Journal of Academic And Business Ethics, East Tennessee State University

Singal, T. (2015). Analisis Pengendalian Intern Piutang Usaha Pada Delevoper 
Branch Kawanua International City. Jurnal Emba, (3)1, 286-296.

Syakur, A. (2015). Intermediate Accounting. Jakarta: Av Publisher.

Taroreh, W. (2016). Evaluasi Penerapan Sistem Pengendalian Internal Piutang Pada PT Mandiri Tunas Finance Cabang Mando. Jurnal Emba, 4(3), 125-134.

Tjodi, S. (2017). Analisis Sistem Pengendalian Internal Piutang Usaha Pada PT. Bank Sulutgo Kcp Ranotama. Jurnal Emba, 5 (2), 857866.

Tuanakotta. (2015). Audit Kontemporer . Jakarta: Salemba Empat. 